\title{
Quantitative extraction of chromium VI and III from tanned leather: a comparative study of pretreatment methods
}

\author{
Mónica Gisel Arellano-Sánchez ${ }^{1}$, Christine Devouge-Boyer ${ }^{1}$, Marie Hubert-Roux ${ }^{2}$, Carlos Afonso ${ }^{2}$ and \\ Mélanie Mignot ${ }^{1 *}$
}

\begin{abstract}
In this study, seven pretreatment methods for chromium speciation in tanned leather were evaluated: acidic mineralization, ethylenediaminetetraacetic acid (EDTA) extraction, diethylenetriaminepentaacetic acid (DTPA) extraction, alkaline extraction $\left(\mathrm{NH}_{4} \mathrm{OH}\right)$, ammonium nitrate extraction $\left(\mathrm{NH}_{4} \mathrm{NO}_{3}\right)$, water extraction, and phosphate buffer extraction. Acidic mineralization permitted the decomposition of the organic matter and ensured the complete digestion of leathers, giving access to the total content of chromium in each sample using inductively coupled plasma-atomic emission spectrometry (ICP-AES). From all the extractant media tested, EDTA proved to be the most efficient, allowing the extraction of $\mathrm{Cr}(\mathrm{VI})$ and $\mathrm{Cr}(\mathrm{III})$ as a $\mathrm{Cr}(\mathrm{III})$-EDTA complex, quantitatively. Method validation is presented for EDTA extraction and direct mineralization. For the EDTA extraction, method detection limit (MDL) and method quantification limit (MQL) for total $\mathrm{Cr}$ in leather were $3.4 \mathrm{ppb}$ and $11.2 \mathrm{ppb}$ ( $\mu \mathrm{g}$ of total $\mathrm{Cr}$ per $\mathrm{L}$ of extraction solution), respectively. Due to the lack of leather certified reference materials (CRMs) for $\mathrm{Cr}(\mathrm{VI})$, accuracy was evaluated by spiking leather samples with a $\mathrm{Cr}(\mathrm{VI})$ solution. The spike recovery of EDTA microwave assisted extraction ranged from 91.0 to $108.6 \%$. Interday precision was also evaluated and all variation coefficients were below $5 \%$, for both mineralization and EDTA extraction. This article provides an efficient procedure to extract quantitatively chromium from leather, while maintaining the speciation, which can be further followed by ion chromatography-inductively coupled plasmamass spectrometry (IC-ICP-MS).
\end{abstract}

Keywords: Hexavalent chromium, Speciation, Tanned leather, Sample pretreatment, EDTA complexation, Inductively coupled plasma

\section{Introduction}

Leather industry occupies a very important role in the development of global economy. Leather is used every day and everywhere in a variety of articles such as footwear, furniture, book covers, gloves, handbags, etc. In order to transform raw hide into leather, a process called tanning is required [1]. Approximately $90 \%$ of all hides

\footnotetext{
*Correspondence: melanie.mignot@insa-rouen.fr

1 UNIROUEN, COBRA UMR CNRS 6014, INSA, Normandie University,

Avenue de l'Université, 76800 Saint-Etienne-du-Rouvray, France

Full list of author information is available at the end of the article
}

are treated with trivalent chromium salts [2]; this process is called chrome-tanning.

The electronic structure of chromium allows it to form coordination complexes, which makes it a remarkable tanning agent (i.e. Cr-collagen complexes via carboxylate functions). Chrome-tanning reaction is fast $(6 \mathrm{~h}$ instead of 3 weeks, compared with vegetable tanning), confers high hydrothermal stability, hardly alters the structure of collagen, makes collagen more hydrophobic (hence, water-resistant), and allows the retention of colorants since $\mathrm{Cr}(\mathrm{III})$ can act as a dye fixing agent [3]. Moreover, the cross-linking of these fibers makes the skin 
insensitive to decay or decomposition, and gives greater stability and resistance to mechanical action and heat.

Even if hides are not directly treated with hexavalent chromium, which is a known carcinogen and mutagen [4], it has been proved that $\mathrm{Cr}(\mathrm{VI})$ can be released from chrome-tanned leather. Indeed, different environmental conditions (i.e. $\mathrm{pH}$, light, temperature ...) can induce trivalent chromium's oxidation into $\mathrm{Cr}(\mathrm{VI})$, as suggested by a recent publication from Fontaine et al. [5]. They studied the storage conditions that could influence the formation of $\mathrm{Cr}(\mathrm{VI})$ in four bovine leather samples, and found that a high temperature, a dry atmosphere, and presence of UV light had a great impact on $\mathrm{Cr}(\mathrm{VI})$ formation, with a predominant role of UV light. Consequently, these conditions should be considered when trying to predict the evolution of chromium in leather goods.

Furthermore, in direct contact with the skin, chrometanned leather products can cause chromium allergy and dermatitis [6, 7]. For most leathers, $\mathrm{Cr}$ (III) is the dominant form of chromium that is released [8-10]. In a recent study, $10 \mathrm{Cr}$-allergic subjects and 22 controls were patch tested with $\mathrm{Cr}(\mathrm{III}), \mathrm{Cr}(\mathrm{VI})$, and leather samples. The results suggested that repeated exposure to Cr-tanned leather with predominantly $\mathrm{Cr}$ (III) release is sufficient to elicit allergic contact dermatitis in $\mathrm{Cr}$ allergic individuals. Even if the majority of $\mathrm{Cr}$-allergic subjects reacted to $\mathrm{Cr}(\mathrm{III})$ and $\mathrm{Cr}(\mathrm{VI})$, a lower dose of $\mathrm{Cr}(\mathrm{VI})$ was required for a stronger reaction [11]. Taking into account that throughout the life-cycle of leather chromium speciation has a dynamic behavior influenced by a large number of parameters, the one-time testing of $\mathrm{Cr}(\mathrm{VI})$ may be considered irrelevant if trivalent chromium is not tested as well. Moreover, no relationship has been found between released $\mathrm{Cr}(\mathrm{III})$ and $\mathrm{Cr}(\mathrm{VI})$ [10]. Besides, an article by Feng et al. [12], reported that both trivalent and hexavalent chromium induce genetic mutations and DNA damage in yeast cells, the effect of $\mathrm{Cr}$ (III) being greater than that of $\mathrm{Cr}(\mathrm{VI})$. Consequently, it is important to quantitatively determine both chromium species separately.

Regarding hexavalent chromium in leather, since 2015 the European Union limits its content to $3 \mathrm{mg} / \mathrm{kg}$ (of the total dry weight) in leather goods coming into direct contact with the skin [13]. However, the European Chemicals Agency has recently adopted an opinion to decrease the restriction limit of hexavalent chromium from 3 to $1 \mathrm{mg} /$ $\mathrm{kg}$ in leather, furs and hides. This shall come into effect 5 years after entry into force of the restriction [14]. Currently, the International Organization for Standardization (ISO) 17075 standard specifies a procedure for the selective extraction of hexavalent chromium in leather using $\mathrm{K}_{2} \mathrm{HPO}_{4} \cdot 3 \mathrm{H}_{2} \mathrm{O}$ at $\mathrm{pH}$ 8.0. Further analysis of the extract is performed via colorimetric [15] or chromatographic analysis [16]. The colorimetric analysis consists of a reaction between $\mathrm{Cr}(\mathrm{VI})$ and 1,5-diphenylcarbazide (DPC), the resulting complex is detected by UV Visible (UV-Vis) spectroscopy at $540 \mathrm{~nm}$. The chromatographic analysis can be performed by direct detection of the chromate peak at $372 \mathrm{~nm}$, or through post-column reaction with DPC by measuring the absorption peak at $540 \mathrm{~nm}$. The limit of quantification (LOQ) of this standard procedure is $3 \mathrm{mg} / \mathrm{kg}$ for both techniques. Table 1 shows a summary of the pretreatment and analytical methods that have been used for the determination of hexavalent chromium in leather samples. All of these techniques rely on a $\mathrm{Cr}(\mathrm{VI})$ extraction with phosphate buffer or $\mathrm{NaOH}$, and then the complexation of hexavalent chromium with DPC for UV-Vis detection. Nevertheless, when working with leather matrices, the selectivity of the UV detection might be compromised as other compounds could absorb at the same wavelength as the target complex; it is important to remark that leather is frequently treated with a variety of chemicals (azo dyes, pigments, fungicides, bactericides, binders, cationic/anionic surfactants...).

However, it can be noticed that there is no current standard describing a method to extract and quantify $\mathrm{Cr}(\mathrm{III})$ and $\mathrm{Cr}(\mathrm{VI})$ simultaneously. A lot of studies have been conducted regarding chromium speciation in other matrices, for example foodstuffs, cosmetic products, environmental, and pharmaceutical samples [20], but as far as we know, the simultaneous extraction of both $\mathrm{Cr}$ species, while maintaining the speciation, has not been studied for leather samples. Fabregat-Cabello et al. [21] reported a focused microwave assisted extraction of $\mathrm{Cr}(\mathrm{VI})$ in several CRMs (soil containing chromite ore processing residue, welding dust loaded on a filter, and sandy clay soil) using EDTA $50 \mathrm{mmol} / \mathrm{L}$ at $\mathrm{pH} 10$. According to their results, they were able to extract and measure $\mathrm{Cr}(\mathrm{VI})$ and $\mathrm{Cr}(\mathrm{III})$-EDTA complex, simultaneously. The separation and analysis of the species was performed by IC-ICP-MS. DTPA has also been tested as chelating agent for trivalent chromium but it has shown lower kinetical stability than EDTA [22]. To extract $\mathrm{Cr}(\mathrm{VI})$ from solid matrices, alkaline extraction with $\mathrm{NH}_{4} \mathrm{OH}$ has been employed for dairy products, flour, chocolate, vegetables, fruits, meat, fish, eggs, and beverages. High-performance liquid chromatography-inductively coupled plasma-mass spectrometry (HPLC-ICP-MS) was used to quantify $\mathrm{Cr}(\mathrm{VI})$ after ultrafiltration of the extract [23]. Gürleyük and Wallschläger [24] reported the successful determination of $\mathrm{Cr}(\mathrm{III})$ and $\mathrm{Cr}(\mathrm{VI})$ in water by IC-ICP-MS using EDTA to derivatize $\mathrm{Cr}(\mathrm{III})$. However, as far as we know, the potential of EDTA to extract $\mathrm{Cr}$ species in leather samples has not been tested. For waters [24, 25], bottom sediments [25], and traditional Chinese medicines [26], chromium species separation has been performed 


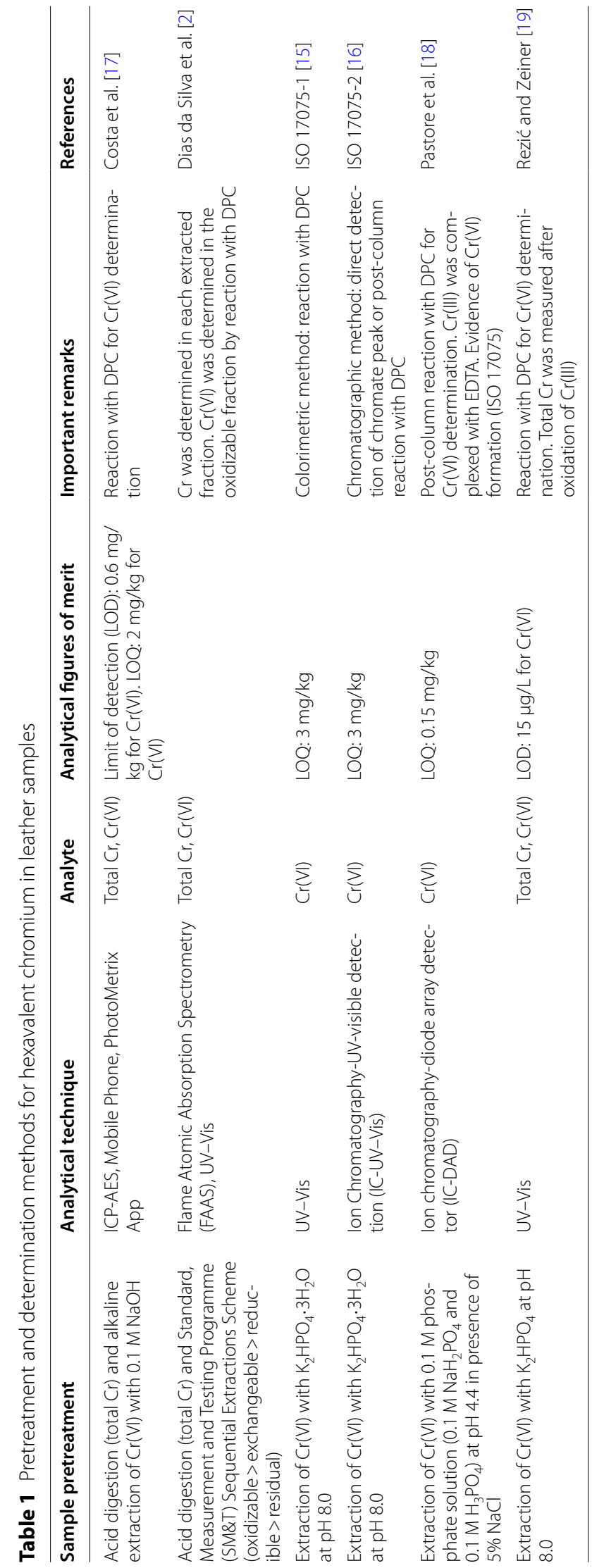


by chromatographic methods using ammonium nitrate as mobile phase after EDTA derivatization or phosphate buffer extraction. Therefore, there is a possibility that if the mobile phase serves to elute both chromium species, it can serve as extraction media as well.

Based on these studies, the objective of this work was to evaluate seven pretreatment methods in tanned leather: acidic mineralization (which permits the decomposition of the organic matter allowing the total $\mathrm{Cr}$ quantification by ICP-AES), EDTA extraction, DTPA extraction, $\mathrm{NH}_{4} \mathrm{OH}$ extraction, ammonium nitrate extraction $\left(\mathrm{NH}_{4} \mathrm{NO}_{3}\right)$, water extraction (for water-soluble chromium compounds), and phosphate buffer extraction (ISO 17075). The efforts in leather research are limited and, to the best of our knowledge, none of these extraction systems have been tried on leather samples. Method validation is presented for EDTA extraction and direct mineralization, and encompassed linearity, accuracy, interday precision, and method detection and quantification limits. IC-ICP-MS using $\mathrm{Cr}$ isotopic standards was performed in order to study the possible $\mathrm{Cr}$ interconversions resulting from the EDTA extraction conditions.

\section{Experimental}

\subsection{Instrumentation}

Extraction and mineralization of samples were performed with a Milestone ETHOS 1 microwave digestion system equipped with a temperature sensor. TFM reactors were used with a maximum pressure of 100 bar. ICP-AES measurements were performed on an iCAP 6300 series instrument (Thermo Fisher Scientific) using the axial view. The quantification of chromium was performed at $283.5 \mathrm{~nm}$. Chromatographic separation was performed using a Dionex ICS-6000 Capillary
HPIC System (Thermo Fisher Scientific). A Dionex ADRS 600 Anion Dynamically Regenerated Suppressor (2 mm) (Thermo Fisher Scientific) was set before the entrance into ICP-MS to avoid salt deposition and was operated in the external regeneration mode. A constant flow of $0.6 \mathrm{~mL} / \mathrm{min}$ of ultrapure water was supplied by means of a Dionex AXP auxiliary pump (Thermo Fisher Scientific). Two guard columns were placed before the analytical column: a Dionex IonPac NG1 $(2 \times 50 \mathrm{~mm}$, particle size: $10 \mu \mathrm{m})$ and a Dionex IonPac AG7 $(2 \times 50 \mathrm{~mm}$, particle size: $10 \mu \mathrm{m})$. Ions were separated with a Dionex IonPac AS7 column $(2 \times 250 \mathrm{~mm}$, particle size: $10 \mu \mathrm{m})$. The analytical column was coupled to the nebulizer of the ICP-MS using a PEEK tubing $(0.25 \mathrm{~mm}$ i.d., $150 \mathrm{~cm}$ long). Detection of chromium species was performed on an iCAP RQ ICP-MS instrument (Thermo Fisher Scientific) fitted with a collision cell. Two different measurement modes were used: standard mode (STD) and kinetic energy discrimination mode (KED). In the KED mode, He gas was injected in the collision cell and an energy discrimination barrier was applied in order to remove unwanted polyatomic interferences. Data processing was performed using ThermoFisher Scientific Qtegra software. As example, optimized conditions for the plasma and nebulizer for ICP-AES and ICP-MS are given in Table 2.

The $\mathrm{pH}$ of the solutions was measured using a PHM240 pH/Ion Meter (MeterLab, Radiometer Analytical, Villeurbanne, France). Centrifugation of the extracts was performed with an Eppendorf Centrifuge 5702. Alkaline and ammonium nitrate extractions were performed using an Elmasonic S ultrasonic bath (Elma, Singen, Germany).

Table 2 Optimized operating conditions for ICP-AES and ICP-MS

\begin{tabular}{lll}
\hline & iCAP 6300 ICP-AES & iCAP RQ ICP-MS \\
\hline Radio frequency power $(\mathrm{W})$ & 1050 & 1550 \\
Plasma gas flow rate $(\mathrm{L} / \mathrm{min})$ & 14 & 14 \\
Auxiliary argon flow rate $(\mathrm{L} / \mathrm{min})$ & 1.0 & 0.8 \\
Nebulizer gas flow rate $(\mathrm{L} / \mathrm{min})$ & 0.5 & 1.0 \\
Purge gas (nitrogen) flow rate $(\mathrm{L} / \mathrm{min})$ & 12 & - \\
Peristatic pump rate $(\mathrm{rpm})$ & 50 & 15 \\
Sample uptake delay $(\mathrm{s})$ & 30 & 30 \\
Replicates & 3 & 3 \\
Rinse time $(\mathrm{s})$ & 30 & 30 \\
Sampler & ASX520-CETAC & SC-2DX (with FAST valve system) \\
& & or online coupling with IC \\
Chamber & Cyclonic & Cyclonic \\
Nebulizer type & Concentric & Concentric \\
\hline
\end{tabular}




\subsection{Materials}

Ultrapure water (resistivity $18.2 \mathrm{MW} \mathrm{cm}$ ), obtained from a Milli-Q system (Millipore, Bedford, MA, USA), was used for preparation of all solutions unless stated otherwise. Nitric acid 67-69\% (Ultrapure Normatom, VWR Chemicals, Leuven, Belgium) was used for the mineralizations. For the extractions, EDTA (Analytical reagent, VWR Chemicals, Leuven, Belgium), DTPA (97\%, Aldrich-Chemie, Germany), $\mathrm{NH}_{4} \mathrm{OH} 20-22 \%$ $\mathrm{NH}_{3}$ (Optima grade, Fisher Scientific, UK), $\mathrm{NH}_{4} \mathrm{NO}_{3}$ (Normapur guaranteed reagent, Prolabo, Paris, France), $\mathrm{K}_{2} \mathrm{HPO}_{4} \cdot 3 \mathrm{H}_{2} \mathrm{O}$ (AnalaR Normapur, VWR Chemicals, Leuven, Belgium), and phosphoric acid (85 wt. \% in $\mathrm{H}_{2} \mathrm{O}$, Sigma-Aldrich, Germany) were employed. Filtration was performed with $0.45 \mu \mathrm{m}$ nylon syringe filters (Fisher Scientific). Potassium dichromate (Normapur guaranteed reagent, Prolabo, Paris, France) was used for preparing calibration standards and spikes. Leather samples came from the luxury industry and were all chrome-tanned and colored. Depending on the treatment they had (chrome-tanned, colored, satin, or glossy leather), their chromium content was not necessarily the same. Consequently, for all the extractions done hereafter, a direct mineralization of the same sample was done to provide each time the reference amount of total chromium. Concerning chromium speciation by IC-ICP-MS, mobile phase was prepared with $\mathrm{NH}_{4} \mathrm{NO}_{3}$ and adjusted to $\mathrm{pH}$ with $\mathrm{HNO}_{3} \cdot{ }^{53} \mathrm{Cr}$ (III) (97.01\%) and ${ }^{50} \mathrm{Cr}(\mathrm{VI})$ (97.36\%) chromium isotopic standards (100 ppm, Certified Reference Material, ISC Science, Oviedo, Spain) were diluted and used to monitor possible chromium interconversions.

\subsection{Total chromium determination}

Leather was either directly mineralized or extracted prior to mineralization of the supernatant to further quantify by ICP-AES the amount of chromium extracted by the different media (EDTA, DTPA, $\mathrm{NH}_{4} \mathrm{OH}, \mathrm{NH}_{4} \mathrm{NO}_{3}$, water, phosphate buffer). After the mineralization process, samples were diluted and total chromium was determined by ICP-AES. The calibration standards were freshly prepared with potassium dichromate and they were acidified as the same level as the samples. A scheme of the methodology is shown in Fig. 1a.

\subsection{Sample preparation}

Dry leather samples were cut into small pieces (3 to $5 \mathrm{~mm}$ per side) in accordance with ISO 4044:2017, 6.3 [27]. They were cut in the laboratory and immediately after this, they were stored in resealable plastic bags. This was done for each sample in the same way during the study. For each pretreatment method, three samples were treated in three different days.

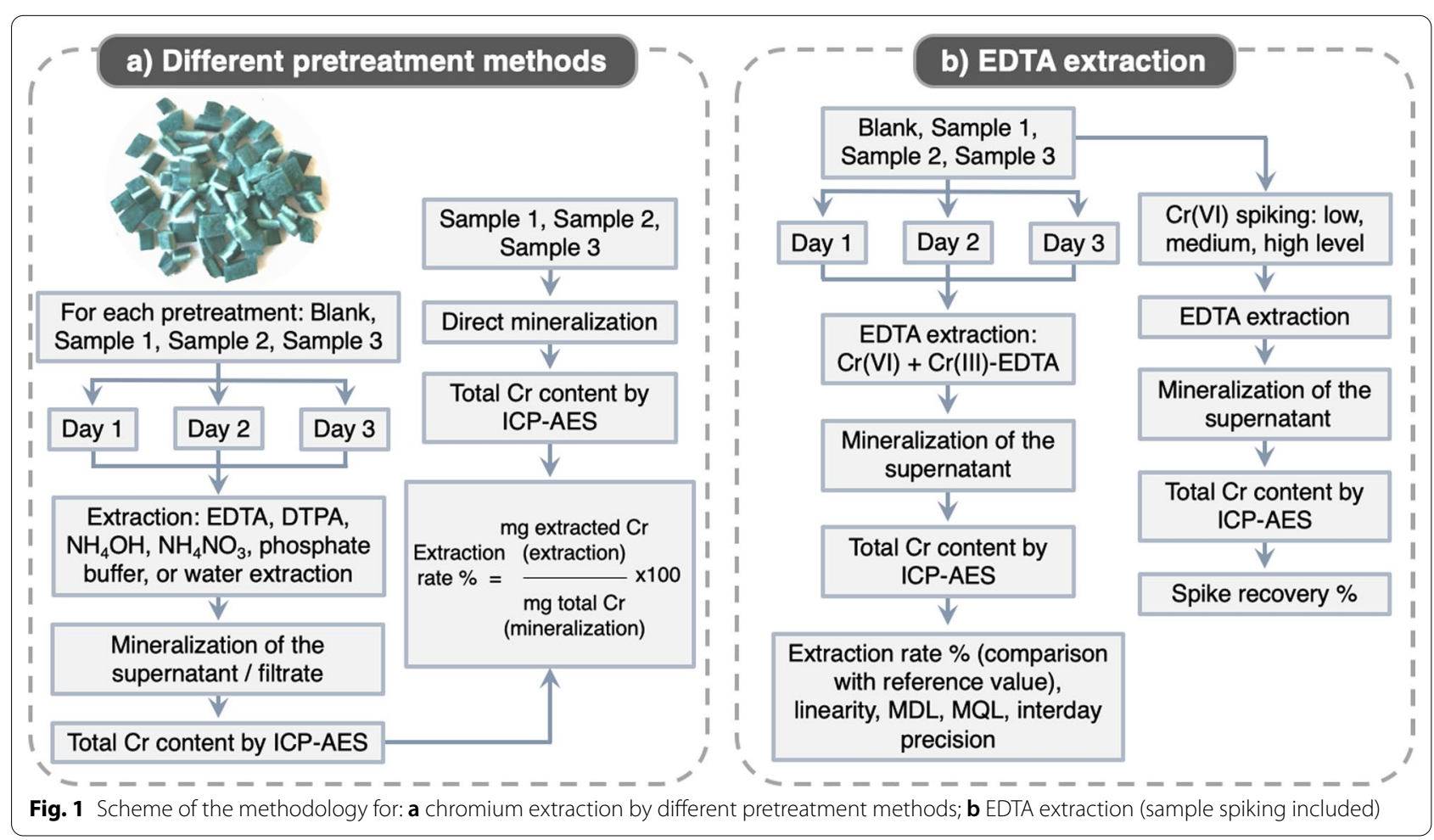




\subsection{Mineralization (or acidic digestion)}

\subsubsection{Direct mineralization of leather}

An amount of $200 \mathrm{mg}$ of leather was digested with $2 \mathrm{~mL}$ of nitric acid at $150{ }^{\circ} \mathrm{C}$ in a microwave system: $10 \mathrm{~min}$ from room temperature, $21{ }^{\circ} \mathrm{C}$, to $150{ }^{\circ} \mathrm{C}, 30 \mathrm{~min}$ at $150{ }^{\circ} \mathrm{C}$. After the mineralization, the digest was diluted up to $50 \mathrm{~mL}$ with water. For total Cr determination by ICP-AES, $1.25 \mathrm{~mL}$ of the last solution were diluted up to $25 \mathrm{~mL}$ with water. Calibration standards were acidified at the same level as the samples.

\subsubsection{Mineralization of the extracts}

Two milliliters of the extract (EDTA, DTPA, $\mathrm{NH}_{4} \mathrm{OH}$, $\mathrm{NH}_{4} \mathrm{NO}_{3}$, water, or phosphate buffer extraction) were digested with $2 \mathrm{~mL}$ of nitric acid at $150{ }^{\circ} \mathrm{C}$ in a microwave system: $10 \mathrm{~min}$ from room temperature, $21^{\circ} \mathrm{C}$, to $150{ }^{\circ} \mathrm{C}, 30 \mathrm{~min}$ at $150{ }^{\circ} \mathrm{C}$. After the mineralization, the digest was diluted up to $50 \mathrm{~mL}$ with water. For total $\mathrm{Cr}$ determination by ICP-AES, $1.25 \mathrm{~mL}$ of the last solution were diluted up to $25 \mathrm{~mL}$ with water. Calibration standards were acidified at the same level as the samples.

\subsection{EDTA extraction}

An amount of $200 \mathrm{mg}$ of leather was extracted with $4 \mathrm{~mL}$ of EDTA $50 \mathrm{mmol} / \mathrm{L}$ (adjusted to $\mathrm{pH} 10$ with $\mathrm{NH}_{4} \mathrm{OH}$ ) at $100{ }^{\circ} \mathrm{C}$ in a microwave system: $10 \mathrm{~min}$ from room temperature, $21{ }^{\circ} \mathrm{C}$, to $100{ }^{\circ} \mathrm{C}, 30 \mathrm{~min}$ at $100{ }^{\circ} \mathrm{C}$. The extract was afterwards centrifuged for $15 \mathrm{~min}$ at $4000 \mathrm{rpm}$, the supernatant was collected and mineralized for further total Cr quantification.

\subsection{DTPA extraction}

Similarly, for the DTPA extraction $200 \mathrm{mg}$ of leather were extracted with $4 \mathrm{~mL}$ of DTPA $50 \mathrm{mmol} / \mathrm{L}$ (adjusted to $\mathrm{pH} 10$ with $\mathrm{NH}_{4} \mathrm{OH}$ ) at $100{ }^{\circ} \mathrm{C}$ in a microwave system: $10 \mathrm{~min}$ from room temperature, $21^{\circ} \mathrm{C}$, to $100{ }^{\circ} \mathrm{C}, 30 \mathrm{~min}$ at $100{ }^{\circ} \mathrm{C}$. The extract was afterwards centrifuged for $15 \mathrm{~min}$ at $4000 \mathrm{rpm}$, the supernatant was collected and mineralized for further total $\mathrm{Cr}$ quantification.

\subsection{Alkaline extraction}

For the alkaline extraction, $500 \mathrm{mg}$ of leather were extracted with $10 \mathrm{~mL}$ of $\mathrm{NH}_{4} \mathrm{OH}$ at ultrasonic bath during $1 \mathrm{~h}$, as previously described by Vacchina et de la Calle [23] for dry food samples. The extract was centrifuged for $15 \mathrm{~min}$ at $4000 \mathrm{rpm}$ and filtered using a nylon $0.45 \mu \mathrm{m}$ filter. Further digestion of the extract was performed before total $\mathrm{Cr}$ quantification.

\subsection{Ammonium nitrate extraction}

An amount of $500 \mathrm{mg}$ of leather was extracted with $10 \mathrm{~mL}$ of $\mathrm{NH}_{4} \mathrm{NO}_{3} 0.1 \mathrm{M}$ at ultrasonic bath for $1 \mathrm{~h}$. After the ultrasonic assisted extraction, the solution was centrifuged for $15 \mathrm{~min}$ at $4000 \mathrm{rpm}$ and filtered using a nylon $0.45 \mu \mathrm{m}$ filter. The digestion of the extract was performed as formerly described.

\subsection{Water extraction}

An amount of $200 \mathrm{mg}$ of leather were extracted with $4 \mathrm{~mL}$ of ultrapure water at $100{ }^{\circ} \mathrm{C}$ in a microwave system: $10 \mathrm{~min}$ from room temperature, $21{ }^{\circ} \mathrm{C}$, to $100{ }^{\circ} \mathrm{C}$, $30 \mathrm{~min}$ at $100^{\circ} \mathrm{C}$. The extract was centrifuged for $15 \mathrm{~min}$ at $4000 \mathrm{rpm}$ and the supernatant was collected. Then, the supernatant was mineralized for total Cr quantification.

\subsection{Phosphate buffer extraction}

In order to evaluate the ISO 17075 standardized method, $500 \mathrm{mg}$ of leather were extracted with $25 \mathrm{~mL}$ of $\mathrm{K}_{2} \mathrm{HPO}_{4} \cdot 3 \mathrm{H}_{2} \mathrm{O}$ at $\mathrm{pH} 8.0$ (adjusted with phosphoric acid) for three hours under magnetic stirring. The extracts were subsequently filtrated through nylon $0.45 \mu \mathrm{m}$ filter and mineralized for total $\mathrm{Cr}$ determination.

\subsection{Sample spiking}

\subsubsection{Sample spiking of mineralization}

An amount of $200 \mathrm{mg}$ of leather was spiked with 1, 3, and $5 \mathrm{mg}$ of $\mathrm{Cr}(\mathrm{VI})$ coming from a concentrated solution of potassium dichromate freshly prepared. Subsequently, the samples were mineralized, diluted, and analyzed by ICP-AES for total Cr quantification.

\subsubsection{Sample spiking of EDTA extraction}

An amount of $200 \mathrm{mg}$ of leather was spiked with 2, 6, and $10 \mathrm{mg}$ of $\mathrm{Cr}(\mathrm{VI})$ with a concentrated solution of potassium dichromate freshly prepared. The samples were extracted with an EDTA solution (as specified in Sect. 2.6) and the supernatant was mineralized as previously specified. After proper dilution, the samples were analyzed by ICP-AES for total $\mathrm{Cr}$ quantification. This methodology is described in Fig. $1 \mathrm{~b}$.

\subsection{Speciation by IC-ICP-MS \\ 2.13.1 Complexation}

In order to follow possible $\mathrm{Cr}$ interconversions during the separation and determination of species through ICICP-MS, $400 \mu \mathrm{L}$ of a $\mathrm{Cr}$ isotopic standard $\left({ }^{53} \mathrm{Cr}(\mathrm{III})\right.$ or ${ }^{50} \mathrm{Cr}(\mathrm{VI})$ ) was complexed with $4 \mathrm{~mL}$ of EDTA $0.5 \mathrm{mmol} / \mathrm{L}$ (diluted from the EDTA extraction solution, specified at 2.6) at $100^{\circ} \mathrm{C}$ in a microwave system: $10 \mathrm{~min}$ from room temperature, $21^{\circ} \mathrm{C}$, to $100{ }^{\circ} \mathrm{C}, 30 \mathrm{~min}$ at $100{ }^{\circ} \mathrm{C}$. Solutions were subsequently diluted and analyzed by IC-ICP-MS.

\subsubsection{Analysis of the samples}

Separation was achieved using $\mathrm{NH}_{4} \mathrm{NO}_{3} 75 \mathrm{mmol} / \mathrm{L}$ (adjusted to $\mathrm{pH} 3$ with $\mathrm{HNO}_{3}$ ) as mobile phase. Analysis were conducted on isocratic mode at a mobile phase flow 
rate of $0.25 \mathrm{~mL} / \mathrm{min}$. The column temperature was set at $20{ }^{\circ} \mathrm{C}$. Monitored signals were ${ }^{50} \mathrm{Cr},{ }^{52} \mathrm{Cr}$, and ${ }^{53} \mathrm{Cr}$.

\section{Results and discussion}

\subsection{Evaluation of different pretreatment methods}

Leather samples coming from the luxury industry were analyzed after going through seven different pretreatment procedures to evaluate their extraction rates. Samples used for these experiments had gone through different manufacturing processes, and were available in limited quantity, hence the content of chromium may vary from one sample to another (i.e. samples used for EDTA extraction were not the same as the samples used for $\mathrm{NH}_{4} \mathrm{OH}$ extraction). Additionally, considering that leather is not manufactured, it is less homogeneous than other materials and chromium content may vary from one area to another. Consequently, for each sample (sample 1, sample 2, sample 3), a specific leather piece was selected, cut into small pieces, and used for the full procedure (day 1 , day 2 , day 3 ). For all the extractions done hereafter (EDTA, DTPA, $\mathrm{NH}_{4} \mathrm{OH}, \mathrm{NH}_{4} \mathrm{NO}_{3}$, water, phosphate buffer extraction), a direct and complete mineralization of the same sample was done to provide each time the reference amount of total chromium, and the extraction rate was calculated with Eq. (1). solubilizes as a $\mathrm{Cr}(\mathrm{OH})_{4}{ }^{-}$complex. Hence the possibility of extracting $\mathrm{Cr}(\mathrm{III})$ using $\mathrm{NH}_{4} \mathrm{OH}$ as extractant.

Regarding the ISO 17075 standard, the phosphate buffer extraction exhibited an extraction rate from 5.1 to $6.6 \%$ of total Cr. As can be seen in Table 3f, total extracted chromium ranges from 700 to $800 \mathrm{mg} / \mathrm{kg}$ which is much higher than the restriction limit for hexavalent chromium. These values reveal that even if the protocol permits to extract hexavalent chromium, it also allows the extraction of a portion of trivalent chromium, present at levels much more important than the restriction limit of $\mathrm{Cr}(\mathrm{VI})$. The selectivity of this method comes from the selective reaction of DPC with $\mathrm{Cr}(\mathrm{VI})$, and the further detection of the complex.

The results for water extraction are shown in Table 3e. An extraction rate of 4.2 to $8.8 \%$ of total $\mathrm{Cr}$ (up to $1130 \mathrm{mg} / \mathrm{kg}$ of total $\mathrm{Cr}$ ) was found when using only water, which implies that by submerging the sample in water and heating it to $100{ }^{\circ} \mathrm{C}$, it is possible to extract some chromium species from leather. Considering that total extracted $\mathrm{Cr}$ was far above the restriction limit for $\mathrm{Cr}(\mathrm{VI})$, it can be affirmed that $\mathrm{Cr}(\mathrm{III})$ has been extracted although not in its entirety. Moreover, it is well-known that while $\mathrm{Cr}(\mathrm{III})$ compounds are barely soluble in water, $\mathrm{Cr}(\mathrm{VI})$ compounds are readily soluble in water [30].

$$
\text { Extraction rate } \%=\frac{\mathrm{mg} \text { of extracted chromium }(\text { extraction })}{\mathrm{mg} \text { of total chromium(direct mineralization })} \times 100
$$

The results are shown in Table 3 and are only valid for the conditions described on the experimental section. The highest extraction rate was achieved with the EDTA extraction, which ranged from 92.5 to $108.3 \%$ of total $\mathrm{Cr}$ (Table 3a). The advantage of the EDTA extraction is that it complexes trivalent chromium decreasing the probability of its conversion to $\mathrm{Cr}(\mathrm{VI})$, and allows the dissolution of insoluble forms of $\mathrm{Cr}(\mathrm{VI})$ [28]. Therefore, it permits the extraction of both $\mathrm{Cr}$ species. A slightly lower rate, from 78.7 to $96.1 \%$ of total Cr, as shown in Table 3b, was obtained with DTPA as extractant, as a consequence of a lower stability of the $[\mathrm{Cr}(\mathrm{DTPA})]^{2-}$ complex [22].

It is well-known that the behavior of chromium species in aqueous media is principally affected by $\mathrm{pH}$ and redox potential. The extraction of hexavalent chromium in environmental samples is generally performed in alkaline media. Under these conditions, redox potential decreases, which promotes the stabilization of $\mathrm{Cr}(\mathrm{VI})$ [29]. For leather samples, $\mathrm{NH}_{4} \mathrm{OH}$ reached an extraction rate from 50.3 to $55.5 \%$ (Table 3c), half of the total chromium content, which means that a relevant part of $\mathrm{Cr}$ (III) was also extracted. At $\mathrm{pH}$ above $6, \mathrm{Cr}$ (III) precipitates as $\mathrm{Cr}(\mathrm{OH})_{3}(\mathrm{~s})$. At higher $\mathrm{pH}$, above 9 , this precipitate
Therefore, there is a possibility that $\mathrm{Cr}(\mathrm{VI})$ has been extracted as well.

According to the results presented in Table 3d, the lowest extraction rate was obtained when using ammonium nitrate as extractant (1.4 to $3.3 \%$ of total $\mathrm{Cr}$ ). Hence, even if ammonium nitrate can be used for the successful elution of chromium species in some chromatographic methods [24-26], it is not an adequate extractant for chromium species in leather.

As mentioned before, a mineralization step succeeded each extraction. Mineralization permits the decomposition of the organic matter in the extract and makes possible the analysis and quantification of total $\mathrm{Cr}$ by ICP-AES. In Fig. 2 we can observe the summary of the results from Table 3. Error bars represent the standard deviation of the three results (three different days) obtained for each sample.

\subsection{Validation of the method}

Due to the high extraction rate obtained with EDTA, and the possibility to preserve speciation from the extraction step until the chromatographic analysis by IC-ICP-MS for example, this method was validated together with 
Table 3 Extraction rates of different pretreatment methods. Comparison between direct mineralization and: a EDTA extraction; $\mathbf{b}$

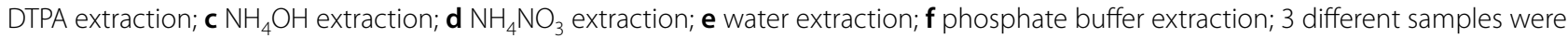
analyzed each day

\begin{tabular}{|c|c|c|c|}
\hline (a) & EDTA & Direct mineralization & \\
\hline Day & $\mathrm{mg}$ of $\mathrm{Cr} / \mathrm{g}$ of sample & $\mathrm{mg}$ of $\mathrm{Cr} / \mathrm{g}$ of sample & $\begin{array}{l}\text { Extraction rate } \\
(\%)\end{array}$ \\
\hline 1 & 12.44 & 12.53 & 99.3 \\
\hline 2 & 13.08 & 12.53 & 104.4 \\
\hline 3 & 13.36 & 12.53 & 106.7 \\
\hline 1 & 12.33 & 12.20 & 101.1 \\
\hline 2 & 13.21 & 12.20 & 108.3 \\
\hline 3 & 12.28 & 12.20 & 100.6 \\
\hline 1 & 11.87 & 12.84 & 92.5 \\
\hline 2 & 12.23 & 12.84 & 95.3 \\
\hline 3 & 12.59 & 12.84 & 98.1 \\
\hline (b) & DTPA & Direct mineralization & \\
\hline Day & $\mathrm{mg}$ of $\mathrm{Cr} / \mathrm{g}$ of sample & $\mathrm{mg}$ of $\mathrm{Cr} / \mathrm{g}$ of sample & $\begin{array}{l}\text { Extraction rate } \\
\text { (\%) }\end{array}$ \\
\hline 1 & 13.91 & 16.12 & 86.3 \\
\hline 2 & 15.07 & 16.12 & 93.5 \\
\hline 3 & 12.68 & 16.12 & 78.7 \\
\hline 1 & 15.13 & 16.57 & 91.3 \\
\hline 2 & 15.18 & 16.57 & 91.6 \\
\hline 3 & 13.86 & 16.57 & 83.6 \\
\hline 1 & 15.47 & 16.33 & 94.7 \\
\hline 2 & 15.70 & 16.33 & 96.1 \\
\hline 3 & 13.82 & 16.33 & 84.6 \\
\hline (c) & $\mathrm{NH}_{4} \mathrm{OH}$ & Direct mineralization & \\
\hline Day & $\mathrm{mg}$ of $\mathrm{Cr} / \mathrm{g}$ of sample & $\mathrm{mg}$ of $\mathrm{Cr} / \mathrm{g}$ of sample & $\begin{array}{l}\text { Extraction rate } \\
\text { (\%) }\end{array}$ \\
\hline 1 & 8.23 & 16.12 & 51.0 \\
\hline 2 & 8.36 & 16.12 & 51.9 \\
\hline 3 & 8.32 & 16.12 & 51.6 \\
\hline 1 & 9.09 & 16.57 & 54.9 \\
\hline 2 & 9.19 & 16.57 & 55.5 \\
\hline 3 & 8.74 & 16.57 & 52.7 \\
\hline 1 & 8.83 & 16.33 & 54.1 \\
\hline 2 & 8.61 & 16.33 & 52.7 \\
\hline 3 & 8.21 & 16.33 & 50.3 \\
\hline (d) & $\mathrm{NH}_{4} \mathrm{NO}_{3}$ & Direct mineralization & \\
\hline Day & $\mathrm{mg}$ of $\mathrm{Cr} / \mathrm{g}$ of sample & $\mathrm{mg}$ of $\mathrm{Cr} / \mathrm{g}$ of sample & $\begin{array}{l}\text { Extraction rate } \\
\text { (\%) }\end{array}$ \\
\hline 1 & 0.48 & 16.12 & 3.0 \\
\hline 2 & 0.31 & 16.12 & 1.9 \\
\hline 3 & 0.23 & 16.12 & 1.4 \\
\hline 1 & 0.54 & 16.57 & 3.3 \\
\hline 2 & 0.42 & 16.57 & 2.6 \\
\hline 3 & 0.27 & 16.57 & 1.6 \\
\hline 1 & 0.42 & 16.33 & 2.5 \\
\hline 2 & 0.32 & 16.33 & 2.0 \\
\hline 3 & 0.28 & 16.33 & 1.7 \\
\hline
\end{tabular}


Table 3 (continued)

\begin{tabular}{|c|c|c|c|}
\hline (e) & Water & Direct mineralization & \\
\hline Day & $\mathrm{mg}$ of $\mathrm{Cr} / \mathrm{g}$ of sample & $\mathrm{mg}$ of $\mathrm{Cr} / \mathrm{g}$ of sample & $\begin{array}{l}\text { Extraction rate } \\
\text { (\%) }\end{array}$ \\
\hline 1 & 0.70 & 12.53 & 5.6 \\
\hline 2 & 0.86 & 12.53 & 6.8 \\
\hline 3 & 0.57 & 12.53 & 4.6 \\
\hline 1 & 0.62 & 12.20 & 5.1 \\
\hline 2 & 0.62 & 12.20 & 5.1 \\
\hline 3 & 0.52 & 12.20 & 4.2 \\
\hline 1 & 0.61 & 12.84 & 4.7 \\
\hline 2 & 1.13 & 12.84 & 8.8 \\
\hline 3 & 0.68 & 12.84 & 5.3 \\
\hline (f) & Phosphate buffer & Direct mineralization & \\
\hline Day & $\mathrm{mg}$ of $\mathrm{Cr} / \mathrm{g}$ of sample & $\mathrm{mg}$ of $\mathrm{Cr} / \mathrm{g}$ of sample & $\begin{array}{l}\text { Extraction rate } \\
\text { (\%) }\end{array}$ \\
\hline 1 & 0.74 & 12.55 & 5.9 \\
\hline 2 & 0.70 & 12.55 & 5.5 \\
\hline 3 & 0.78 & 12.55 & 6.2 \\
\hline 1 & 0.71 & 11.84 & 6.0 \\
\hline 2 & 0.71 & 11.84 & 6.0 \\
\hline 3 & 0.78 & 11.84 & 6.6 \\
\hline 1 & 0.75 & 13.61 & 5.5 \\
\hline 2 & 0.70 & 13.61 & 5.1 \\
\hline 3 & 0.80 & 13.61 & 5.9 \\
\hline
\end{tabular}

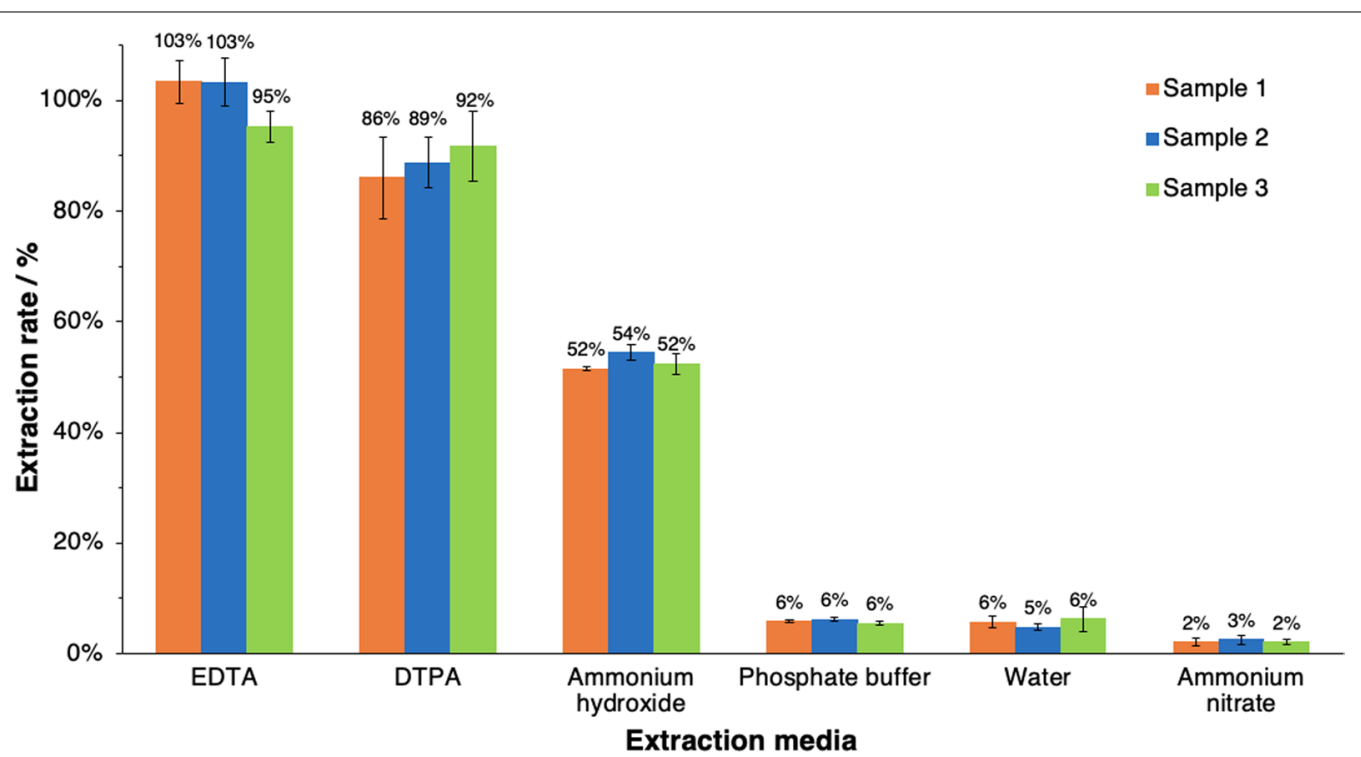

Fig. 2 Summary of extraction rates of six different pretreatment methods (3 samples per method)

the mineralization method. Linearity, Method Detection Limit (MDL), Method Quantification Limit (MQL), interday precision, and recovery are presented in the following subsections.

\subsubsection{Linearity}

Linearity was studied through the analysis of calibration solutions of $\mathrm{Cr}(\mathrm{VI})$ from 0 to $10 \mathrm{mg} / \mathrm{L}(\mathrm{n}=6)$. Each time, the standards were prepared with the same amount 
of nitric acid as the real samples and total $\mathrm{Cr}$ was determined in each solution. Calibration curve was done each day a sample was analyzed, and linearity was found to be 0.9998 for all ICP-AES analyses performed throughout this study.

\subsubsection{Method detection limit and method quantification limit}

MDL and MQL were estimated by the analysis of three blanks and three replicates per blank ( 9 measurements in total). Blanks consisted of the extraction solutions (nitric acid for the mineralization and EDTA $50 \mathrm{mmol} / \mathrm{L}$ $\mathrm{pH} 10$ for the EDTA extraction) and had gone through all the steps of pretreatment and analysis, in the same way as leather samples. For the 9 measurements, a standard deviation was obtained. With this value, MDL was calculated as 3 times the standard deviation $(3 \sigma)$ and MQL was calculated as 10 times the standard deviation $(10 \sigma)$. For the mineralization method, MDL and MQL for total $\mathrm{Cr}$ in leather were $3.9 \mathrm{ppb}$ and $13.1 \mathrm{ppb}$ ( $\mu \mathrm{g}$ of total $\mathrm{Cr}$ per L of mineralization solution), respectively. MDL and MQL for the EDTA extraction were 3.4 ppb and $11.2 \mathrm{ppb}$ of total $\mathrm{Cr}$ ( $\mu \mathrm{g}$ of total $\mathrm{Cr}$ per $\mathrm{L}$ of extraction solution), respectively.

\subsubsection{Interday precision}

Interday precision was determined by analyzing three different leather samples in three different days. It can be noticed in Table 4 that for each sample the interday precision provided a relative standard deviation (RSD) below 5\%, for EDTA extraction and mineralization. Low RSD values show that both methods exhibit excellent interday precision.

\subsubsection{Spike recovery}

Due to the lack of leather certified reference materials for $\mathrm{Cr}(\mathrm{VI})$, accuracy was evaluated by spiking leather samples with a concentrated $\mathrm{Cr}(\mathrm{VI})$ solution prepared with potassium dichromate. Sample spiking was performed at three different levels of spike (low, medium, high), three different samples per level, the same day. For each level, total $\mathrm{Cr}$ was determined by ICP-AES after proper extraction, mineralization, and dilution. This allowed to measure the matrix effects. As observed in Table 5, the spike recovery for the mineralization ranged from 80.1 to $95.2 \%$, so the recovery was good at all spike levels. Same tendency was found for EDTA extraction, as recovery ranged from 91.0 to $108.6 \%$ for all spike levels. Both techniques provided acceptable results, which proved that EDTA extraction was efficient to quantitatively extract

Table 4 Interday precision of: a direct mineralization; b EDTA extraction. 3 different samples were analyzed each day

\begin{tabular}{|c|c|c|c|c|}
\hline \multirow{2}{*}{$\begin{array}{l}\text { (a) } \\
\text { Day }\end{array}$} & \multicolumn{4}{|c|}{ Direct mineralization } \\
\hline & \multicolumn{4}{|c|}{$\mathrm{mg}$ of $\mathrm{Cr} / \mathrm{g}$ of sample $\pm \mathrm{SD}$} \\
\hline 1 & \multicolumn{2}{|c|}{$17.01 \pm 0.10$} & Average & 16.12 \\
\hline 2 & \multicolumn{2}{|c|}{$15.51 \pm 0.02$} & SD & 0.789 \\
\hline 3 & \multicolumn{2}{|c|}{$15.83 \pm 0.09$} & RSD $\%$ & $4.9 \%$ \\
\hline 1 & \multicolumn{2}{|c|}{$17.07 \pm 0.01$} & Average & 16.57 \\
\hline 2 & \multicolumn{2}{|c|}{$16.26 \pm 0.02$} & SD & 0.431 \\
\hline 3 & \multicolumn{2}{|c|}{$16.39 \pm 0.04$} & $\mathrm{RSD} \%$ & $2.6 \%$ \\
\hline 1 & \multicolumn{2}{|c|}{$16.73 \pm 0.03$} & Average & 16.33 \\
\hline 2 & \multicolumn{2}{|c|}{$16.25 \pm 0.03$} & SD & 0.367 \\
\hline 3 & \multicolumn{2}{|c|}{$16.00 \pm 0.03$} & RSD $\%$ & $2.2 \%$ \\
\hline \multirow{2}{*}{$\begin{array}{l}\text { (b) } \\
\text { Day }\end{array}$} & \multicolumn{4}{|l|}{ EDTA extraction } \\
\hline & Extraction rate (\%) & \multicolumn{2}{|c|}{$\mathrm{mg}$ of $\mathrm{Cr} / \mathrm{g}$ of sample $\pm \mathrm{SD}$} & \\
\hline 1 & 99.3 & $12.44 \pm 0.08$ & Average & 12.96 \\
\hline 2 & 104.4 & $13.08 \pm 0.06$ & SD & 0.473 \\
\hline 3 & 106.7 & $13.36 \pm 0.12$ & RSD\% & $3.6 \%$ \\
\hline 1 & 101.1 & $12.33 \pm 0.02$ & Average & 12.61 \\
\hline 2 & 108.4 & \multicolumn{2}{|l|}{$13.21 \pm 0.00$} & 0.526 \\
\hline 3 & 100.7 & $12.28 \pm 0.02$ & RSD\% & $4.2 \%$ \\
\hline 1 & 92.5 & $11.87 \pm 0.02$ & Average & 12.23 \\
\hline 2 & 95.3 & $12.23 \pm 0.02$ & SD & 0.360 \\
\hline 3 & 98.1 & $12.59 \pm 0.03$ & RSD\% & $2.9 \%$ \\
\hline
\end{tabular}


Table 5 Spike recovery for: a direct mineralization; b EDTA extraction

\begin{tabular}{|c|c|c|}
\hline \multirow{2}{*}{$\begin{array}{l}\text { (a) } \\
\text { Spiked Cr (mg) }\end{array}$} & \multicolumn{2}{|c|}{ Direct mineralization } \\
\hline & Found $(\mathrm{mg}) \pm S D$ & \% Recovery \\
\hline 1.00 & $0.80 \pm 0.02$ & 80.1 \\
\hline 1.00 & $0.93 \pm 0.00$ & 93.6 \\
\hline 1.00 & $0.95 \pm 0.01$ & 95.2 \\
\hline 2.99 & $2.67 \pm 0.05$ & 89.4 \\
\hline 2.99 & $2.68 \pm 0.02$ & 89.6 \\
\hline 2.99 & $2.68 \pm 0.03$ & 89.5 \\
\hline 4.98 & $4.47 \pm 0.01$ & 89.7 \\
\hline 4.98 & $4.64 \pm 0.06$ & 93.1 \\
\hline 4.98 & $4.58 \pm 0.03$ & 91.8 \\
\hline (b) & \multicolumn{2}{|l|}{ EDTA extraction } \\
\hline Spiked Cr (mg) & Found $(\mathrm{mg}) \pm \mathrm{SD}$ & $\%$ Recovery \\
\hline 2.00 & $2.17 \pm 0.00$ & 108.6 \\
\hline 2.00 & $2.08 \pm 0.01$ & 103.9 \\
\hline 2.00 & $1.96 \pm 0.01$ & 98.1 \\
\hline 6.00 & $5.67 \pm 0.02$ & 94.4 \\
\hline 6.00 & $5.46 \pm 0.02$ & 91.0 \\
\hline 6.00 & $5.93 \pm 0.01$ & 98.9 \\
\hline 10.00 & $9.67 \pm 0.02$ & 96.6 \\
\hline 10.00 & $9.37 \pm 0.02$ & 93.7 \\
\hline 10.00 & $9.55 \pm 0.02$ & 95.4 \\
\hline
\end{tabular}

the hexavalent chromium that was used to spike the samples, as well as the total $\mathrm{Cr}$ content from leather.

\subsection{Speciation by IC-ICP-MS}

Regarding chromium speciation, IC-ICP-MS analyses were performed in order to verify if the EDTA extraction conditions permit to preserve chromium speciation. This was demonstrated by analyzing $\mathrm{Cr}$ isotopic standards. The analyses were carried out in the standard mode. KED mode was also performed but not differences were perceived. Figure 3a shows the chromatogram obtained from a ${ }^{50} \mathrm{Cr}(\mathrm{VI})$ solution. As can be seen, $\mathrm{Cr}(\mathrm{VI})$ elutes at $920 \mathrm{~s}$ and there is no other peak in the chromatogram. Figure $3 \mathrm{~b}$ corresponds to a Chromium(III) isotopic reference standard enriched in ${ }^{53} \mathrm{Cr}$, which was complexed with EDTA at the same conditions as the EDTA extraction used for leather. In this case, it is possible to observe that a ${ }^{53} \mathrm{Cr}$ (III)-EDTA complex was formed and it eluted at 230 s. An unidentified small peak with a retention time of $150 \mathrm{~s}$ was also noticed. Nevertheless, no peak was observed around $920 \mathrm{~s}$. Thus, these conditions did not induce a conversion from $\mathrm{Cr}(\mathrm{III})$ to $\mathrm{Cr}(\mathrm{VI})$. Figure 3c corresponds to a Chromium(VI) isotopic reference standard enriched in ${ }^{50} \mathrm{Cr}$. This solution was submitted to the same conditions as the EDTA extraction used for leather. As it was expected, no complex was formed as EDTA complexes only with $\mathrm{Cr}$ (III). Anyhow, it is possible to see, when zooming in, two small peaks with a retention time of 150 and $230 \mathrm{~s}$. Each of these peaks represent $1.5 \%$ of the principal peak. The peak with a retention time of $150 \mathrm{~s}$ has not been identified. On the other hand, the retention time of the second peak corresponds to that of the $\mathrm{Cr}$ (III)-EDTA complex. Consequently, in the reverse direction, there is a conversion from $\mathrm{Cr}(\mathrm{VI})$ to $\mathrm{Cr}(\mathrm{III})$ under these extraction conditions, but this conversion is minimal. From this study, we can conclude that the EDTA extraction conditions allowed quantitative chromium extraction while limiting chromium interconversions. An ongoing study focuses on different leathers samples (chrome-tanned, colored, satin, or glossy leather), extracted with EDTA as presented in this study, and analyzed by IC-ICP-MS. Different analysis conditions are tested to give access to the amount of both species $(\mathrm{Cr}(\mathrm{III})$ and $\mathrm{Cr}(\mathrm{VI}))$, with the same protocol (extraction and chromatographic method).

\section{Conclusions}

This work focused on the extraction of chromium from leather samples. On the one hand, the acidic digestion allowed the complete mineralization and gave access to the total chromium content in each sample, but such conditions do not preserve chromium speciation as 

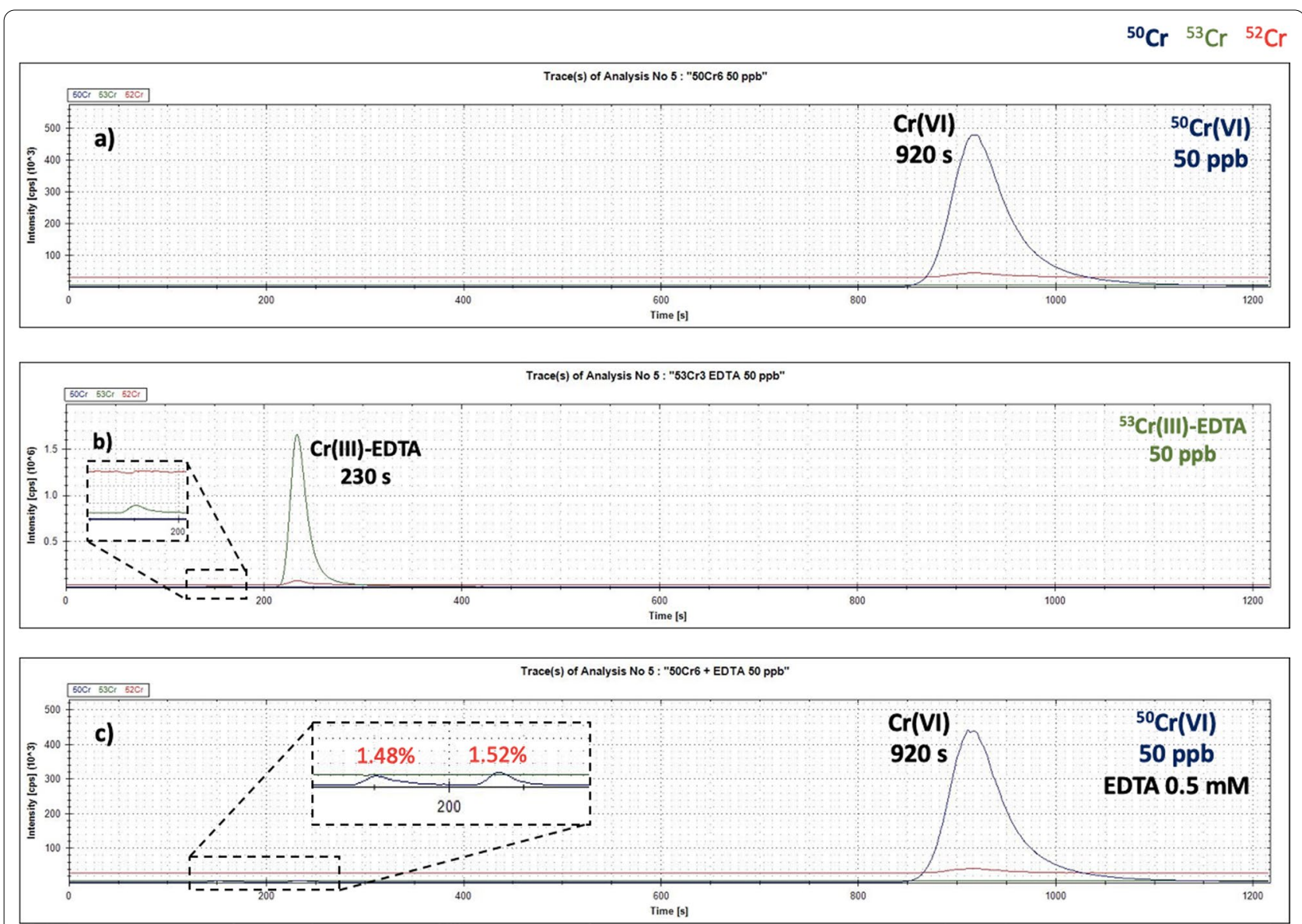

Fig. 3 IC-ICP-MS chromatograms of: a a solution containing $50 \mathrm{ppb}$ of ${ }^{50} \mathrm{Cr}(\mathrm{VII})$, b a solution containing $50 \mathrm{ppb}$ of ${ }^{53} \mathrm{Cr}(\mathrm{III})$ complexed with EDTA $0.5 \mathrm{mmol} / \mathrm{L}$, and $\mathbf{c}$ a solution containing $50 \mathrm{ppb}$ of ${ }^{50} \mathrm{Cr}(\mathrm{VI})$ and EDTA $0.5 \mathrm{mmol} / \mathrm{L}$

$\mathrm{Cr}(\mathrm{VI})$ is reduced to $\mathrm{Cr}(\mathrm{III})$. Among the extraction conditions tested (i.e. EDTA, DTPA, $\mathrm{NH}_{4} \mathrm{OH}, \mathrm{NH}_{4} \mathrm{NO}_{3}$, water, phosphate buffer), EDTA proved to be the most efficient and ensured quantitative extraction of $\mathrm{Cr}(\mathrm{VI})$ and $\mathrm{Cr}(\mathrm{III})$ as a $\mathrm{Cr}(\mathrm{III})$-EDTA complex. The content of total chromium obtained by the EDTA extraction was similar to the content obtained by direct mineralization. The method was validated in terms of linearity, recovery, interday precision, method detection limit, and method quantification limit. The separation of the extracted species was studied through IC-ICP-MS using $\mathrm{Cr}$ isotopic standards, which proved that the EDTA extraction conditions permit a quantitative extraction while limiting the interconversions. No interconversion from $\mathrm{Cr}(\mathrm{III})$ to $\mathrm{Cr}(\mathrm{VI})$ was noticed, and a limited portion $(1.5 \%)$ of $\mathrm{Cr}(\mathrm{VI})$ was transformed into $\mathrm{Cr}(\mathrm{III})$ under the extraction conditions used.

\section{Abbreviations}

CRMs: Certified reference materials; DPC: 1,5-Diphenylcarbazide; DTPA: Diethylenetriaminepentaacetic acid; EDTA: Ethylenediaminetetraacetic acid; FAAS:
Flame atomic absorption spectrometry; HPLC-ICP-MS: High-performance liquid chromatography-inductively coupled plasma-mass spectrometry; IC-DAD: Ion chromatography-diode array detector; IC-ICP-MS: Ion chromatographyinductively coupled plasma-mass spectrometry; IC-UV-Vis: lon chromatography-UV-visible detection; ICP-AES: Inductively coupled plasma-atomic emission spectrometry; ISO: International Organization for Standardization; KED: Kinetic energy discrimination mode; LOD: Limit of detection; LOQ: Limit of quantification; MDL: Method detection limit; MQL: Method quantification limit; RSD: Relative standard deviation; SM\&T: Standard, measurement and testing programme; STD: Standard mode; UV-Vis: UV visible spectroscopy.

\section{Acknowledgements}

Not applicable.

\section{Authors' contributions}

MGAS performed the extractions, analyzed, and interpreted the data. CDB and MHR were in charge of the instrumentation. CA was in charge of getting the funding and provision of equipment. MM corrected the manuscript and leaded scientific discussions. All authors read and approved the final manuscript.

\section{Funding}

This work has been partially supported by University of Rouen Normandy, INSA Rouen Normandy, the Centre National de la Recherche Scientifique (CNRS), European Regional Development Fund (ERDF) No HN0001343, Labex SynOrg (ANR-11-LABX-0029), Carnot Institute I2C, the graduate school for research XL-Chem (ANR-18-EURE-0020 XL CHEM), Region Normandie, and Consejo Nacional de Ciencia y Tecnología (CONACYT CVU 707668). IC 
instrument has been financed by RIN LabEx Milliflux No 19 E00566 and ICP/MS through Bioenairgy project (FEDER No HN0001343).

\section{Availability of data and materials}

The datasets analyzed during the current study are available from the corresponding author on reasonable request.

\section{Declarations}

\section{Competing interests}

The authors declare no competing interests.

\section{Author details}

${ }^{1}$ UNIROUEN, COBRA UMR CNRS 6014, INSA, Normandie University, Avenue de I'Université, 76800 Saint-Etienne-du-Rouvray, France. ${ }^{2}$ UNIROUEN, COBRA, UMR CNRS 6014, IRCOF, Normandie University, 76821 Mont-Saint-Aignan Cedex, France.

Received: 30 March 2021 Accepted: 30 September 2021

Published online: 15 November 2021

\section{References}

1. IL \& FS Environment. Technical EIA guidance manual for leather/skin/hide processing industry prepared for The Ministry of Environment and Forest, Government of India. 2010.

2. Dias da Silva LI, Marinho Pontes FV, Castro Carneiro M, Couto Monteiro Ml, Dominguez de Almeida M, Alcover Neto A. Evaluation of the chromium bioavailability in tanned leather shavings using the SM\&T sequential extractions scheme. Chem Speciat Bioavailab. 2011;23:183-7.

3. Covington AD, Wise WR. Tanning chemistry: the science of leather. 2nd ed. London: Royal Society of Chemistry; 2019.

4. IARC monographs on the evaluation of carcinogenic risks to humans. Chromium, nickel and welding. Lyon, France; 1990.

5. Fontaine M, Clement $Y$, Blanc N, Demesmay C. Hexavalent chromium release from leather over time natural ageing vs accelerated ageing according to a multivariate approach. J Hazard Mat. 2019;368:811-8.

6. Thyssen JP, Jensen P, Carlsen BC, Engkilde K, Menné T, Johansen JD. The prevalence of chromium allergy in Denmark is currently increasing as a result of leather exposure: the development of chromium allergy. $\mathrm{Br} J$ Dermatol. 2009;161:1288-93.

7. Thyssen JP, Menné T, Johansen JD. Hexavalent chromium in leather is now regulated in European Union member states to limit chromium allergy and dermatitis. Contact Derm. 2014;70:1-2.

8. Hedberg YS, Lidén C, Odnevall WI. Chromium released from leatherI: exposure conditions that govern the release of chromium(III) and chromium(VI). Contact Derm. 2015;72:206-15.

9. Hedberg YS, Wei Z, Matura M. High release of hexavalent chromium into artificial sweat in a case of leather shoe-induced contact dermatitis Contact Derm. 2020:82:179-81.

10. Hedberg YS. Chromium and leather: a review on the chemistry of relevance for allergic contact dermatitis to chromium. J Leather Sci Eng. 2020;2:15.

11. Hedberg YS, Erfani B, Matura M, Lidén C. Chromium(III) release from chromium-tanned leather elicits allergic contact dermatitis: a use test study. Contact Derm. 2018:78:307-14.

12. Fang Z, Zhao M, Zhen H, Chen L, Shi P, Huang Z. Genotoxicity of tri- and hexavalent chromium compounds in vivo and their modes of action on DNA damage in vitro. PLOS ONE. 2014;9:1-9.

13. Commission Regulation (EU) No $301 / 2014$ amending Annex XVII to Regu lation (EC) No 1907/2006 of the European Parliament and of the Council on the Registration, evaluation, authorisation and restriction of chemicals (REACH) as regards chromium VI compounds. Off J Eur Union. 2014;25;3.

14. European Chemicals Agency. Opinion on an Annex XV dossier proposing restrictions on Skin sensitising substances [Internet]. 2020. Available from: https://echa.europa.eu/de/registry-of-restriction-intentions/-/dislist/detai Is/0b0236e182446136.

15. International Organization for Standardization. ISO 17075-1:2017 [IULTCS/ IUC 18-1] Leather-chemical determination of chromium(VI) content in leather-Part 1: Colorimetric method [Internet]. 2017. Available from: https://www.iso.org/standard/67096.html.

16. International Organization for Standardization. ISO 17075-2:2017 [IULTCS/ IUC 18-2] Leather-Chemical determination of chromium(VI) content in leather-Part 2: Chromatographic method [Internet]. 2017. Available from: https://www.iso.org/standard/67097.html.

17. Costa V, Neiva A, Pereira-Filho E. Chromium speciation in leather samples: an experiment using digital images, mobile phones and environmental concepts. Ecletica Quim J. 2019;44:62-74.

18. Pastore $P$, Favaro G, Ballardin A, Danieletto D. Evidence of $\mathrm{Cr}(\mathrm{VI})$ formation during analysis of leather. Talanta. 2004;63:941-7.

19. Rezić I, Zeiner M. Determination of extractable chromium from leather. Monatsh Chem. 2009;140:325-8.

20. Arellano-Sánchez MG, Devouge-Boyer C, Hubert-Roux M, Afonso C, Mignot M. Chromium determination in leather and other matrices: a review. Crit Rev Anal Chem. 2021;1-20.

21. Fabregat-Cabello N, Rodríguez-González P, Castillo Á, Malherbe J, RoigNavarro AF, Long SE, et al. Fast and accurate procedure for the determination of $\mathrm{Cr}(\mathrm{VI})$ in solid samples by isotope dilution mass spectrometry. Environ Sci Technol. 2012;46:12542-9.

22. Chen Z, Megharaj M, Naidu R. Speciation of chromium in waste water using ion chromatography inductively coupled plasma mass spectrometry. Talanta. 2007;72:394-400

23. Vacchina V, de la Calle I, Séby F. Cr(VI) speciation in foods by HPLC-ICPMS: investigation of $\mathrm{Cr}(\mathrm{VI})$ /food interactions by size exclusion and $\mathrm{Cr}(\mathrm{VI})$ determination and stability by ion-exchange on-line separations. Anal Bioanal Chem. 2015:407:3831-9.

24. Gürleyük H, Wallschläger D. Determination of chromium(III) and chromium(VI) using suppressed ion chromatography inductively coupled plasma mass spectrometry. J Anal At Spectrom. 2001;16:926-30.

25. Jabłońska-Czapla M, Szopa S, Grygoyć K, Łyko A, Michalski R. Development and validation of HPLC-ICP-MS method for the determination inorganic $\mathrm{Cr}$, As and Sb speciation forms and its application for Pławniowice reservoir (Poland) water and bottom sediments variability study. Talanta. 2014;120:475-83.

26. Li P, Li L, Xia J, Cao S, Hu X, Lian H-Z, et al. Determination of hexavalent chromium in traditional Chinese medicines by high-performance liquid chromatography with inductively coupled plasma mass spectrometry: liquid chromatography. J Sep Sci. 2015;38:4043-7.

27. International Organization for Standardization. ISO 4044:2017 LeatherChemical tests_-preparation of chemical test samples. 2017.

28. Korolczuk M, Grabarczyk M. Evaluation of ammonia buffer containing EDTA as an extractant for $\mathrm{Cr}(\mathrm{VI})$ from solid samples. Talanta. 2005;66:1320-5.

29. Unceta N, Séby F, Malherbe J, Donard OFX. Chromium speciation in solid matrices and regulation: a review. Anal Bioanal Chem. 2010;397:1097-111.

30. Ertani A, Mietto A, Borin M, Nardi S. Chromium in agricultural soils and crops: a review. Water Air Soil Pollut. 2017;228:1-12.

\section{Publisher's Note}

Springer Nature remains neutral with regard to jurisdictional claims in published maps and institutional affiliations. 